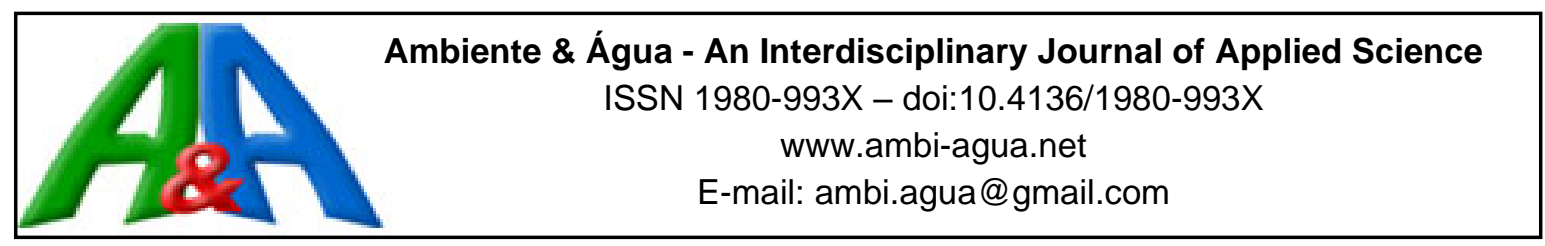

\title{
Mixed greywater treatment for irrigation uses
}

\author{
ARTICLES doi:10.4136/ambi-agua.2599
}

Received: 15 Jun. 2020; Accepted: 08 Oct. 2020

\begin{abstract}
Eli Morales Rojas ${ }^{1 * i D}$; Jesús Rascón ${ }^{1}{ }^{\mathbb{D}}$; Lenin Quiñones Huatangari2 ${ }^{\circledR}$; Segundo Chavez Quintana1 ${ }^{1 D}$; Manuel Oliva1(id); Manuel Emilio Milla Pino ${ }^{3}$

${ }^{1}$ Instituto de Investigación para el Desarrollo Sustentable de Ceja de Selva. Universidad Nacional Toribio Rodríguez de Mendoza de Amazonas (UNTRM), Calle Higos Urco, n 342-350-356, 01001,

Chachapoyas, Amazonas, Peru. E-mail: jesus.rascon@untrm.edu.pe, segundo.quintana@untrm.edu.pe, manuel.oliva@untrm.edu.pe

${ }^{2}$ Facultad de Ingeniería de Industrias Alimentarias. Universidad Nacional de Jaén (UNJ), Jirón Cuzco, n² 250, 06801, Jaén, Cajamarca, Peru. E-mail: lenin.quinones@unj.edu.pe

${ }^{3}$ Facultad de Ingeniería Civil. Universidad Nacional de Jaén (UNJ), Jirón Cuzco, n ${ }^{\circ}$ 250, 06801, Jaén, Cajamarca, Peru. E-mail: memilla22@yahoo.com.mx

*Corresponding author. E-mail: eli.morales@untrm.edu.pe
\end{abstract}

\begin{abstract}
Water contamination comes from many different sources, including, among others, factories, sewage treatment plants, mining activities (heavy metals), food-processing waste, agriculture runoff, animal waste, disposal of personal care products, and household chemicals. Therefore, the reuse of wastewater has become a fundamental strategy for sustainable water management and maintaining environmental quality. In this sense, this research presents a simple and economic alternative to solving the problems caused by greywater, resulting from laundry activities. This paper evaluates a mixed system for the treatment of greywater. The mixed system has physical filters that are composed of river stone, concrete, river sand, and coal. A bioremediation technique is also evaluated, involving two types of aquatic plants, watercress (Nasturtium officinale L.) and duckweed (Lemma minor L.). This study showed significant differences in $\mathrm{pH}$ reduction, from 9.56 to 7.50 , total suspended solids (TSS), from $1742.00 \mathrm{mg} / \mathrm{L}$ to $298.50 \mathrm{mg} / \mathrm{L}$, phosphates, from $1.12 \mathrm{mg} / \mathrm{L} \mathrm{PO}_{4}{ }^{3-}$ to $0.31 \mathrm{mg} / \mathrm{L} \mathrm{PO}_{4}{ }^{3-}$, and chemical oxygen demand (COD), from $472.38 \mathrm{mg} / \mathrm{L}$ to $8.52 \mathrm{mg} / \mathrm{L}$. Thus, the results indicate that this system is efficient for the reuse of grey water for irrigation uses. Moreover, each parameter, with the exception of dissolved oxygen and total suspended solids (TSS), meets the maximum limits set by the Environmental Quality Standards for Category 3: irrigation water for vegetables and animal beverages and the FAO irrigation water standards.
\end{abstract}

Keywords: biological filter, detergents, macrophytes, physical filter, water quality.

\section{Sistema misto de tratamento de águas cinzas para irrigação}

\section{RESUMO}

As atividades pelas indústrias, população urbana e rural, são fontes mais frequentes na poluição de água, devido nisso tem se tornado necessário, principalmente a reutilização das águas resíduas como uma estratégia fundamental. Nesse sentido esta pesquisa apresenta uma alternativa simples e econômica para solucionar os problemas causados pela água cinzas das atividades de lavanderia doméstica, com o objetivo de avaliar um sistema misto de tratamento de água cinza. Para isso foi estabelecido um sistema misto com filtração física, compostos de pedra de rio, concreto, areia de rio e carvão, seguido pela Biorremediação com duas plantas 
aquáticas, agrião (Nasturtium officinale L.) e lentilha d'água (Lemma minor L.). Os resultados tiveram diferenças significativas na redução do $\mathrm{pH}$ de 9.56 até 7.50, os sólidos suspensos totais (SST) de $1742.00 \mathrm{mg} / \mathrm{L}$ até $298.50 \mathrm{mg} / \mathrm{L}$, os fosfatos de $1,12 \mathrm{mg} / \mathrm{L} \mathrm{PO}_{4}{ }^{3-}$ até $0,31 \mathrm{mg} / \mathrm{L} \mathrm{PO}_{4}{ }^{3-}$ e demanda química de oxigênio (DQO) de $472,38 \mathrm{mg} / \mathrm{L}$ até $8,52 \mathrm{mg} / \mathrm{L}$, por tanto indicam que o sistema é eficiente para o reuso da água cinzas com fim de irrigação. Finalmente, todos os parâmetros, a diferença do oxigênio dissolvido e os sólidos suspensos totais (SST), cumprem com os limites máximos permitidos pelos padrões de qualidade ambiental para a categoria três: água de irrigação para vegetais e bebidas de animais e os padrões para irrigação pela FAO.

Palavras-chave: detergentes, filtro biológico, filtro físico, macrófitas, qualidade da água.

\section{INTRODUCTION}

Water is one of the essential resources for the development of natural life in all its forms (Cai et al., 2016). However, the importance of this resource has not been taken into account until the end of the 19th century, when it was discovered as the origin of numerous water-related infectious diseases (Abellán, 2017). Moreover, the scarcity and deterioration of water resources have been related to anthropological activities, for example, poor agriculture practices, livestock, and mining, along with accelerated industrial development and rapid population growth (Bwapwa, 2018). All these factors lead to health problems due to deficient water consumption (Guzmán et al., 2016). In developing countries, such as Peru, most diseases are caused by poor water supply (Ferro-Mayhua et al., 2019).

The service of water supply and sanitation is a major problem in Peru (Calzada et al., 2017). Accordingly, by the beginning of 2018, an estimated $10.6 \%$ of the Peruvian population lacked access to drinking water services in the public system. Furthermore, the inadequate disposal of greywater outside the sewerage system is of great concern. As a result, there is an increase in the proliferation of vector-borne diseases that affect the most vulnerable population (Gutierrez-Espino and Romero-Cóndor, 2018). Greywater or sullage is the result of laundry activities, showers, baths, hand basins, and washing machines. These waste waters usually have hazardous contaminants such as phosphate, a typical compound in detergents, which causes the eutrophication of water bodies (Fowdar et al., 2017; Pérez-Díaz et al., 2019).

Those water issues are a major concern in the search for new supply sources and treatment systems, as well as finding alternatives to mitigate the environmental impacts caused by the inadequate disposal of greywater. In fact, water is a valuable resource that must be preserved in order to ensure a permanent supply for a sustainable use. There are a large number of techniques for treating wastewater, which range from conventional techniques, mostly physical and chemical, such as sedimentation, filtration or chlorination, to alternative techniques, generally physical and biological, such as bioremediation or filtration involving inert material such as sand or gravel (Ghernaout et al., 2017; Poirier et al., 2019). Alternative techniques, although not generally used by both national and local government bodies, may be part in the response to greywater treatment in rural or low-finance areas, as they are proven to be efficient in removing organic and inorganic pollutants and pathogenic organisms (Boczkaj and Fernandes, 2017).

Regarding alternative treatments, bioremediation is one of the most important techniques that is increasingly used due to its easy and simple use and its friendliness to the environment (Azubuike et al., 2016). These techniques usually involve planting emergent plants, such as watercress (Nasturtium officinale L.); but in some cases, organisms such as worms have also been considered. It has been proven that the use of Californian worms (Eisenia fetida, Savigny, 1826) or water hyacinth (Eichhornia crassipes (Mart.) Solms) is highly effective in treating and purifying greywater, especially in terms of organic matter parameters which include

Rev. Ambient. Água vol. 15 n. 6, e2599 - Taubaté 2020 
biochemical oxygen demand $\left(\mathrm{BOD}_{5}\right)$ or chemical oxygen demand (COD) (Reyes Farje and Morales Rojas, 2019).

In this sense, this work proposes a mixed treatment system based on bioremediation and filtration techniques to treat greywater which is generated in a building, testing the evolution of the physicochemical parameters throughout the system. Furthermore, we analyze the spatial variation of the physicochemical parameters in the system and, finally, determine whether the parameters meet national and international regulations and standards regarding water usage in the irrigation of vegetables.

\section{MATERIALS AND METHODS}

\subsection{Study Area}

The experiment was conducted in the building "La Alianza Alemana", with an average population of 18 people and an age distribution of the occupants above 18 years. This building is located in the province of Chachapoyas, Amazonas in northern Peru. It is located at an altitude of 2483 meters above sea level, between the coordinates $6^{\circ} 13^{\prime} 00^{\prime \prime} \mathrm{S}$ and $77^{\circ} 51^{\prime} 00^{\prime \prime} \mathrm{O}$.

\subsection{Mixed system design}

The mixed treatment system for the purification of greywater has two parts, which are connected to each other. The first one is a grey water collection system, with a capacity of 100 litres, with the purpose of adequately feeding the filter systems of the following component. The second part has three mechanical filters, each with a capacity of 600 litres, and whose measurements are $100 \mathrm{~cm}$ in width per $100 \mathrm{~cm}$ in length and $60 \mathrm{~cm}$ in depth. Each filter's base is composed of three layers; the first layer has $0.24 \mathrm{~m} 3$ of 1 " river stone, the second one of 0.04 $\mathrm{m} 3$ of concrete, and the last one of $0.24 \mathrm{~m} 3$ of sand mixed with $0.06 \mathrm{~m} 3$ of coal generated from wood. Furthermore, in the third filter, we also included two bioremediation plants, duckweed (Lemma minor L) and watercress (Nasturtium officinale L), which were distributed in equal parts. It was taken an average height of 10 centimetres into account for the aforementioned plants, thus ensuring their proper development (Figure 1).

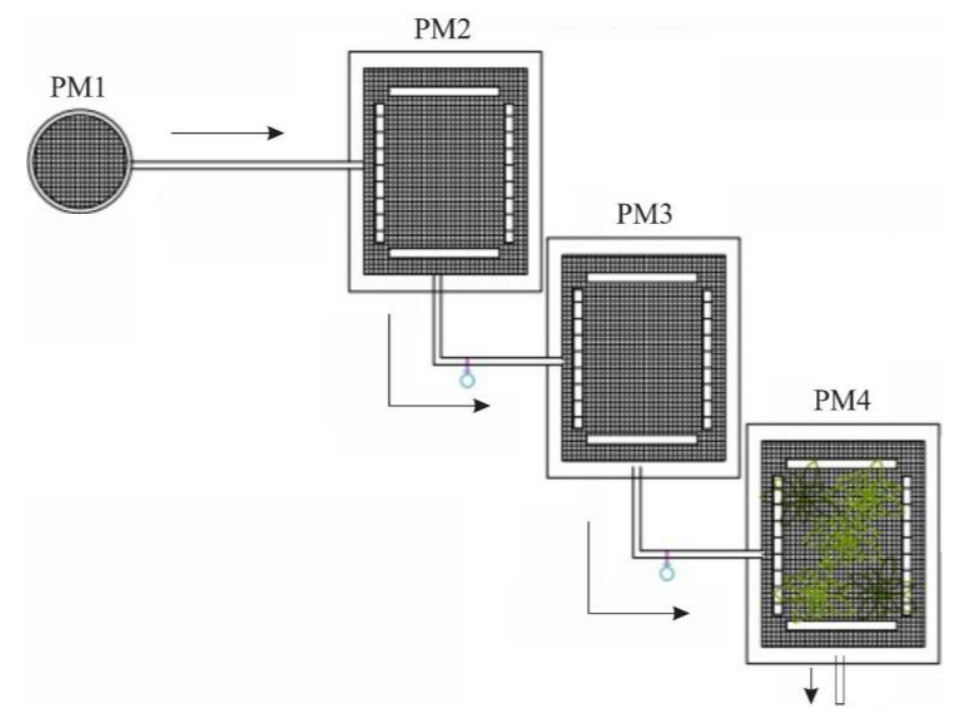

Figure 1. Design of the mixed treatment system based on filtration and bioremediation techniques (PM1: Collection, PM2: Filter 1, PM3: Filter 2, PM4: Filter 3)

\subsection{Methodology}

Sampling was carried out every 15 days between June and July 2018. For each established sampling point (PM1, PM2, PM3 and PM4) we collected four samples. The collection, storage, 
and transfer of samples, including laboratory analysis, were done according to APHA et al. (2017). Moreover, data collection of $\mathrm{pH}$ and Dissolved Oxygen (DO) was performed on-site using a Hanna Model HI 98194 multiparametric water test. The samples to determine biochemical oxygen demand $\left(\mathrm{BOD}_{5}\right)$ and chemical oxygen demand $(\mathrm{COD})$, parameters that establish the contamination of organic matter in water bodies, were collected in dark plastic containers and transparent plastic bottles, thereby allowing the physicochemical analysis of electrical conductivity (EC), total dissolved solids (TDS), total suspended solids (TSS), alkalinity and phosphates. Such analyses were performed at the Soil and Water Laboratory of the Research Institute for the Sustainable Development of the "Ceja de Selva" (INDES-CES) from the National University Toribio Rodriguez de Mendoza de Amazonas.

\subsection{Statistical analysis}

First of all, a graphic analysis of the box and whiskers of each parameter per sampling point was created to study the behaviour of the parameters in each part of the system. Likewise, a Kruskal-Walis analysis of each parameter was made and subsequently a post-hoc test, a Mann-Whitney test with the Bonferroni adjustment method, was carried out on the parameters that showed significant differences, in the interest of identifying the existence of differences between individual parts of the system, and thus being able to compare the behaviour and interrelationship at the inflow and outflow stages of the system. To understand the relationship between the studied parameters, a Spearman correlation analysis was performed. Finally, it was verified graphically whether all the parameters met the maximum permitted limits for $\mathrm{pH}, \mathrm{DO}$, EC, Alkalinity, BOD and COD, set by the Environmental Quality Standards (EQS) of Water for Category 3: irrigation water for vegetables and animal beverages, established by the Ministry of Environment, Peru (2017). Due to the fact that the parameters of TDS, TSS and phosphate are not included in the EQS, they were tested with standards established by the Food and Agriculture Organization of the United Nations (FAO) for water quality in agriculture (Ayers and Westcot, 1994). All statistical analyses were performed at a significance level of $\mathrm{p}<0.05$ with the statistical software R v. 3.6.3 (R Development Core Team, 2020).

\section{RESULTS AND DISCUSSION}

\subsection{Performance of the physicochemical parameters in the mixed treatment system}

We found that the parameters that showed a reduction throughout the treatment system are $\mathrm{pH}$ ranging from 9.56 to 7.50 , DO from $6.58 \mathrm{mg} / \mathrm{L}$ to $3.13 \mathrm{mg} / \mathrm{L}$, TSS from $1742.00 \mathrm{mg} / \mathrm{L}$ to $298.50 \mathrm{mg} / \mathrm{L}$, alkalinity from $106.06 \mathrm{mg} / \mathrm{L}$ to $76 \mathrm{mg} / \mathrm{L}$, phosphates from $1.12 \mathrm{mg} / \mathrm{L}$ to 0.31 $\mathrm{mg} / \mathrm{L}, \mathrm{BOD}$ from $28.13 \mathrm{mg} / \mathrm{L}$ to $12.31 \mathrm{mg} / \mathrm{L}$ and COD from $472.38 \mathrm{mg} / \mathrm{L}$ to $8.52 \mathrm{mg} / \mathrm{L}$. On the other hand, the parameters that experienced an increase are EC rising from $186.75 \mu \mathrm{S} / \mathrm{cm}$ to $328.25 \mu \mathrm{S} / \mathrm{cm}$ and TDS from $112.05 \mathrm{mg} / \mathrm{L}$ to $196.95 \mathrm{mg} / \mathrm{L}$ (Figure 2).

It should be noted that $\mathrm{pH}$ is one of the parameters which is most affected by the mixed treatment system, as it has been reduced from alkaline to almost neutral (Figure 2A). This performance can also be observed in fast, slow and mixed sand filters for obtaining drinking water (Laghari et al., 2018). In fact, this parameter has enormous importance in wastewater treatment, due to the high influence on biological, chemical or physical treatments (Aelterman et al., 2006; Issabayeva and Dih, 2019). As an example of this, it is relevant in the ammonium oxidation process (Tomaszewski et al., 2017), in advanced oxidation processes (Boczkaj and Fernandes, 2017), as well as in microbiological processes for the elimination of phosphorus (Stokholm-Bjerregaard et al., 2017).

Rev. Ambient. Água vol. 15 n. 6, e2599 - Taubaté 2020 

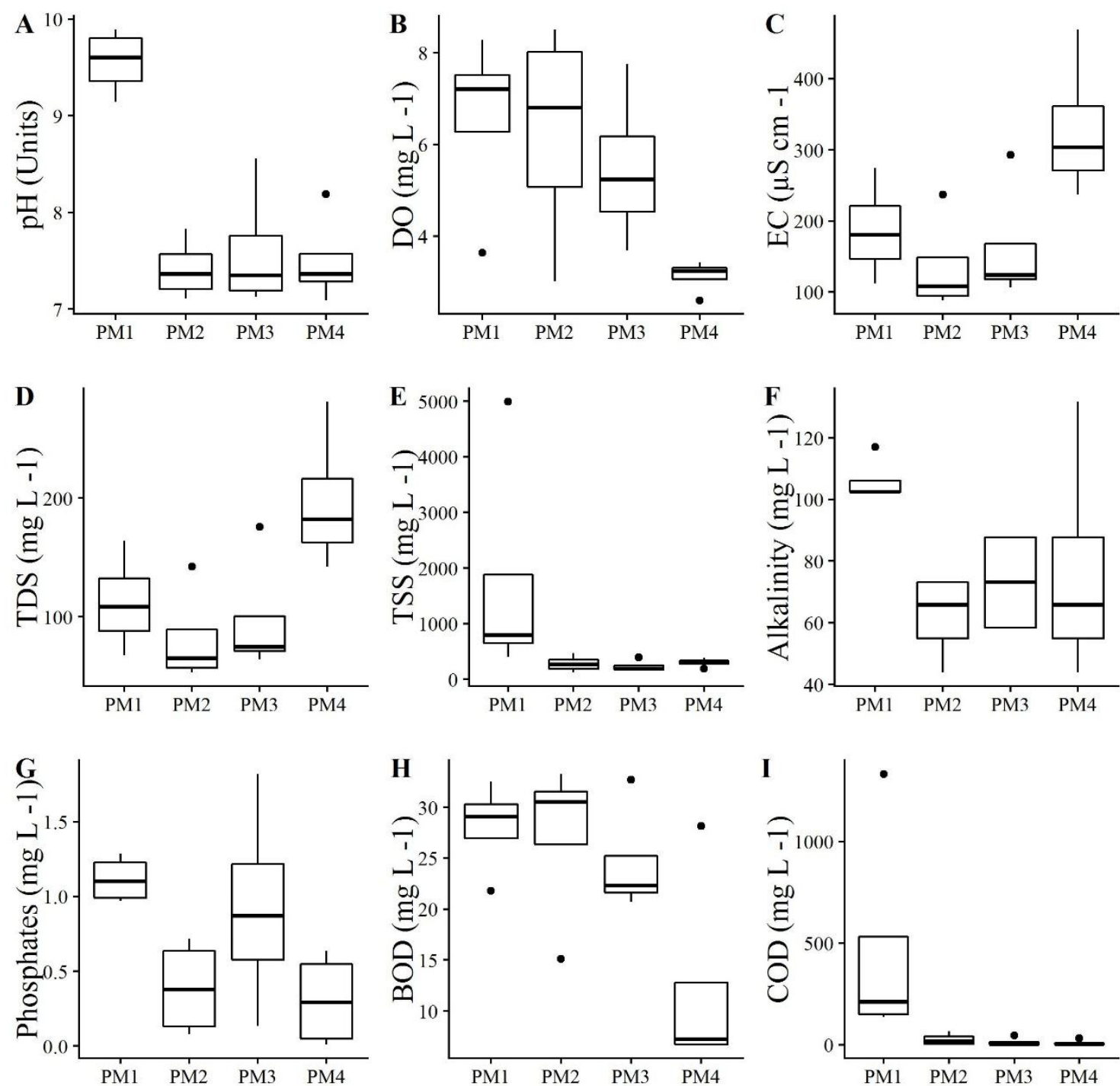

Figure 2. Average values of $\mathrm{pH}(\mathrm{A}), \mathrm{DO}(\mathrm{B}), \mathrm{EC}(\mathrm{C})$, TDS (D), TTS (E), Alkalinity (F), Phosphates $(\mathrm{G})$, BOD $(\mathrm{H}), \mathrm{COD}(\mathrm{I})$ at the different sampling points in the system.

In contrast, regarding DO, it was negatively affected since it had a significant decrease (Figure 2B). Usually this is typical at the bottom of oxidation ponds (Noikondee et al., 2019). However, DO reduction is very common in biological treatments, since oxygen consumption is an excellent indicator that the system works properly (Harja et al., 2016). Nevertheless, it would be ideal to include an additional method in this system to increase DO, given that it is essential to biodegrade contaminants, especially organic matter (Radzi et al., 2020).

In relation to EC and TDS parameters, which are directly related to each other, they experience an increase along the treatment system points (Figure $2 \mathrm{C}$ and 2D). These parameters usually decrease when biological treatments are applied (Duque-Sarango et al., 2018). This behavior is due to the dragging of particles in the system when the filters contain sand and carbon (Pompei et al., 2017). Nevertheless, just the opposite occurs with TSS (Figure 2E), owing to the fact that there are seasonal phases in the filter, and in the absence of pumps, sedimentation processes, therefore take place, leading to a settling of solid particles to the bottom (Merizalde et al., 2019).

The alkalinity decreased from Point PM1 to Point PM2 of the treatment; however, it was constant in the remaining points (Figure 2F). Alkalinity is an important parameter, not only because it varies according to the type of treatment and temperature, but also because it is an indicator for making $\mathrm{pH}$ adjustments in the systems, as it is strongly related to it, and thus 
prevents corrosion or incrustation in the treatment systems (Silva-Teira et al., 2018). The reduction of phosphate (Figure $2 \mathrm{G}$ ) is mainly due to assimilation by aquatic plants, since it is an important nutrient for their growth (Delgadillo-Mirquez et al., 2016).

The organic matter, BOD and COD parameters showed a large decrease throughout the mixed system (Figure $2 \mathrm{H}$ and 2I). The same inclinations are found in other water treatments, for instance, stabilization or oxidation ponds, which, by degrading organic matter and oxygenating it, have proven to be efficient, reducing up to $82 \%$ of organic matter (Peña et al., 2018). Similarly, it has been shown that aquatic plants are efficiently removing organic matter in the range of 70-86\% when using Eichhornia crassipes (Mart.) Solms, and about 58\% when using Lemma minor L, both of which are used in this research (Rodríguez-Miranda et al., 2010).

\subsection{Spatial dynamics for the mixed treatment system}

The Kruskal-Wallis analysis for the nine physicochemical parameters showed significant differences for $\mathrm{pH}$, TSS, Phosphates and COD (Table 1). After applying the post-hoc test (Mann-Whitney test), it was found that point number one of the systems differs from the rest of the treatment system

Table 1. Kruskal-Wallis analysis and post-hoc test (Mann-Whitney test) for the analyzed physicochemical parameters.

\begin{tabular}{|c|c|c|c|c|}
\hline \multirow{2}{*}{ Parameters } & \multicolumn{2}{|c|}{ Kruskal-Wallis } & \multicolumn{2}{|c|}{ Post-hoc } \\
\hline & $\chi^{2}$ & Sig. & Different PM & Same PM \\
\hline pH (Units) & 8.54 & $0.036^{*}$ & 1 & $3,4,2$ \\
\hline $\mathrm{DO}(\mathrm{mg} / \mathrm{L})$ & 6.77 & $0.079^{\mathrm{ns}}$ & \multicolumn{2}{|c|}{ Same } \\
\hline $\mathrm{EC}(\mu \mathrm{S} / \mathrm{cm})$ & 7.48 & $0.057^{\mathrm{ns}}$ & \multicolumn{2}{|c|}{ Same } \\
\hline TDS (mg/L) & 7.48 & $0.058^{\mathrm{ns}}$ & \multicolumn{2}{|c|}{ Same } \\
\hline TSS (mg/L) & 8.25 & $0.041 *$ & 1 & $3,4,2$ \\
\hline Alkalinity (mg/L) & 6.55 & $0.088^{\mathrm{ns}}$ & \multicolumn{2}{|c|}{ Same } \\
\hline Phosphates (mg/L) & 8.76 & $0.033 *$ & 1 & $2,4,3$ \\
\hline $\mathrm{BOD}_{5}(\mathrm{mg} / \mathrm{L})$ & 5.87 & $0.118^{\mathrm{ns}}$ & \multicolumn{2}{|c|}{ Same } \\
\hline $\mathrm{COD}(\mathrm{mg} / \mathrm{L})$ & 10.41 & $0.015^{*}$ & 1 & $2,3,4$ \\
\hline
\end{tabular}

*Significant $(\mathrm{P}<0.05),{ }^{\mathrm{ns}}$ not significant $(\mathrm{P}>0.05)$.

As for the $\mathrm{pH}$, TSS, phosphates and COD parameters, those parameters have been affected by the mixed treatment system (Table 1). Both $\mathrm{pH}$ and TSS are significantly affected by the action of mechanical filters, due to the retention of particles larger than $0.45 \mu \mathrm{m}$ (Laghari et al., 2018) and the effect of calcium carbonate that is usually found in the sand (Holtman et al., 2018). The significant effects on phosphates are due to the action of aquatic plants when using them as a nutrient (Delgadillo-Mirquez et al., 2016), whereas the effects on COD are mainly due to the path taken by the water through the various mechanical filters, which promotes oxygenation and thus the degradation of organic matter (Achak et al., 2019).

\subsection{Water quality testing of the mixed treatment system}

Regarding water warmth evolution, it is noted that at the beginning, all parameters meet the regulations, but $\mathrm{pH}$, TSS, BOD and COD. On the other hand, at the end of the treatment, the only parameters that fail to meet the regulations are the DO and the TSS (Figure 3).

If we compare the final values of $\mathrm{pH}, \mathrm{OD}, \mathrm{EC}$, Alkalinity, $\mathrm{BOD}$ and $\mathrm{COD}$ parameters with the Environmental Quality Standards (EQS) for Water, Category 3: irrigation water for vegetables and animal beverages, established by the Peruvian Ministry of the Environment (Peru, 2017), we find that they all meet the standard, except for the DO. TDS, TSS and 
phosphate parameters were compared with the standards established by the FAO, for water quality in agriculture, given that Peruvian regulations do not include them within the RCTs (Figure 3). Although $\mathrm{pH}$ is not widely used to assess irrigation water quality, it is important to establish the relative concentrations of dissolved carbonate species, which affect plant nutrient uptake (Jaramillo and Restrepo, 2017).
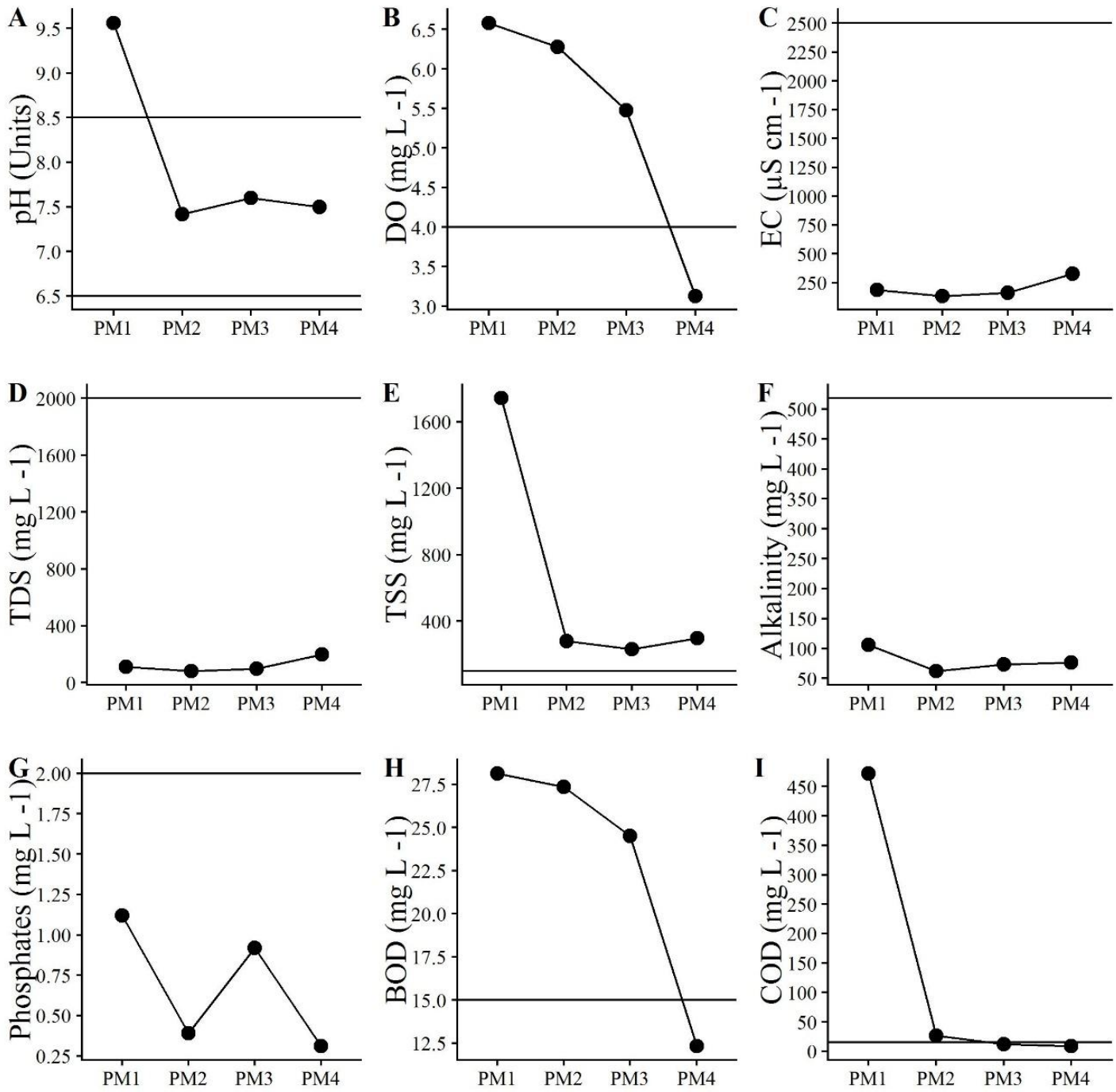

Figure 3. Comparison of average values of $\mathrm{pH}(\mathrm{A})$, DO (B), EC (C), TDS (D), TTS (E), Alkalinity (F), Phosphates (G), BOD (H), COD (I) regulations.

Parameters which are of primary importance for irrigation include phosphates and organic matter (BOD and COD), due to their strong influence on plant growth (Da Silva Gomes et al., 2019). Nevertheless, low DO concentration has a major disadvantage, since values found to be lower than $3.0 \mathrm{mg} / \mathrm{L}$ make biota survival impossible (Rubio Arias et al., 2014). Therefore, one option may be the implementation of air pumps, in order for the DO values to be increased. Both TDS and phosphates meet the limits established by the FAO. However, TSS exceeds the maximum limit allowed. Nevertheless, that limit is only for drip irrigation to avoid clogging (Ayers and Westcot, 1994). This means that we can use them for direct irrigation.

\section{CONCLUSIONS}

Our results demonstrated that the mixed treatment system improved greywater quality for irrigation uses, notably by reducing levels of $\mathrm{pH}$, TSS, phosphates, BOD and COD. As a result, 
these parameters were favourably influenced in each system filter. Nevertheless, the EC and TDS parameters were negatively affected by the sediment carry-over in the treatment system, as well as the DO reaching lower values for the development of biota.

Finally, all final values of parameters meet the FEA and FAO standards for irrigation water, except the DO. Therefore, we suggest implementing an aeration system within the treatment.

\section{REFERENCES}

ABELLÁN, J. Water supply and sanitation services in modern Europe: developments in 19th 20th centuries. In: INTERNATIONAL CONGRESS OF THE SPANISH ASSOCIATION OF ECONOMIC HISTORY, 12., 6-9 Sep. 2017, Salacamca. Proceedings[...] Salamanca: University of Salamanca, 2017.

ACHAK, M.; BOUMYA, W.; OUAZZANI, N.; MANDI, L. Preliminary evaluation of constructed wetlands for nutrients removal from olive mill wastewater (OMW) after passing through a sand filter. Ecological Engineering, v. 136, p. 141-151, 2019. https://doi.org/10.1016/j.ecoleng.2019.06.007

AELTERMAN, P.; RABAEY, K.; CLAUWAERT, P.; VERSTRAETE, W. Microbial fuel cells for wastewater treatment. Water Science and Technology, v. 54, n. 8, p. 9-15, 2006. https://doi.org/10.2166/wst.2006.702

APHA; AWWA; WEF. Standard Methods for the examination of water and wastewater. 23nd ed. Washington, 2017. 1504 p.

AYERS, R. S.; WESTCOT, D. W. Water quality for agriculture. Roma: FAO, 1994. 85 p.

AZUBUIKE, C. C.; CHIKERE, C. B.; OKPOKWASILI, G. C. Bioremediation techniquesclassification based on site of application: principles, advantages, limitations and prospects. World Journal of Microbiology and Biotechnology, v. 32, n. 11, p. 1-18, 2016. https://doi.org/10.1007/s11274-016-2137-x

BOCZKAJ, G.; FERNANDES, A. Wastewater treatment by means of advanced oxidation processes at basic pH conditions: A review. Chemical Engineering Journal, v. 320, p. 608-633, 2017. https://doi.org/10.1016/j.cej.2017.03.084

BWAPWA, J. K. Review on Main Issues Causing Deterioration of Water Quality and Water Scarcity: Case Study of South Africa. Environmental Management and Sustainable Development, v. 7, n. 3, p. 14-34, 2018. https://doi.org/10.5296/emsd.v7i3.13156

CAI, Y.; YUE, W.; XU, L.; YANG, Z.; RONG, Q. Sustainable urban water resources management considering life-cycle environmental impacts of water utilization under uncertainty. Resources, Conservation and Recycling, v. 108, p. 21-40, 2016. https://doi.org/10.1016/j.resconrec.2016.01.008

CALZADA, J.; IRANZO, S.; SANZ, A. Community-Managed Water Services: The Case of Peru. Journal of Environment and Development, v. 26, n. 4, p. 400-428, 2017. https://doi.org/10.1177/1070496517734020

DA SILVA GOMES, J. W.; DA SILVA DIAS, N.; MORENO PIZANI, M. A. Growth and mineral composition of the melon with different doses of phosphorus and organic matter. Dyna, v. 86, n. 211, p. 363-368, 2019. https://doi.org/10.15446/dyna.v86n211.69776 
DELGADILLO-MIRQUEZ, L.; LOPES, F.; TAIDI, B.; PAREAU, D. Nitrogen and phosphate removal from wastewater with a mixed microalgae and bacteria culture. Biotechnology Reports, v. 11, p. 18-26, 2016. https://doi.org/10.1016/j.btre.2016.04.003

DUQUE-SARANGO, P.; HERAS-NARANJO, C.; LOJANO-CRIOLLO, D. Modelamiento del tratamiento biológico de aguas residuales; estudio en planta piloto de contactores biológicos rotatorios. Revista Ciencia UNEMI, v. 11, p. 88-96, 2018.

FERRO-MAYHUA, F.; FERRÓ-GONZALES, P. F.; FERRÓ-GONZALES, A. L. Distribución temporal de las enfermedades diarreicas agudas, su relación con la temperatura y cloro residual del agua potable en la ciudad de Puno, Perú. Journal of High Andean Research, v. 21, n. 1, p. 69-80, 2019. https://doi.org/10.18271/ria.2019.446

FOWDAR, H. S.; HATT, B. E.; BREEN, P.; COOK, P. L. M.; DELETIC, A. Designing living walls for greywater treatment. Water Research, v. 110, p. 218-232, 2017. https://doi.org/10.1016/j.watres.2016.12.018

GHERNAOUT, D.; BADIS, A.; BRAIKIA, G.; MATÂAM, N.; FEKHAR, M.; GHERNAOUT, B.; BOUCHERIT, A. Enhanced coagulation for algae removal in a typical Algeria water treatment plant. Environmental Engineering and Management Journal, v. 16, n. 10, p. 2303-2315, 2017. https://doi.org/10.30638/eemj.2017.238

GUTIERREZ-ESPINO, C.; ROMERO-CÓNDOR, E. Perú: Formas de acceso a agua y sanemiento básico. Lima: INEI, 2018.

GUZMÁN, B. L.; NAVA, G.; BEVILACQUA, P. D. Vigilancia de la calidad del agua para consumo humano en Colombia: desafíos para la salud ambiental. Revista Facultad Nacional de Salud Pública, v. 34, n. 2, p. 175-183, 2016. https://doi.org/10.17533/udea.rfnsp.v34n2a06

HARJA, G.; NASCU, I.; MURESAN, C.; NASCU, I. Improvements in dissolved oxygen control of an activated sludge wastewater treatment process. Circuits, Systems, and Signal Processing, v. 35, n. 6, p. 2259-2281, 2016. https://doi.org/10.1007/s00034016-0282-y

HOLTMAN, G. A.; HALDENWANG, R.; WELZ, P. J. Biological sand filter system treating winery effluent for effective reduction in organic load and $\mathrm{pH}$ neutralisation. Journal of Water Process Engineering, v. 25, p. 118-127, 2018. https://doi.org/10.1016/j.jwpe.2018.07.008

ISSABAYEVA, G.; DIH, J. C. M. Rubber industry wastewater treatment: Adsorption of zinc. AIP Conference Proceedings, v. 2157, 2019. https://doi.org/10.1063/1.5126547

JARAMILLO, M. F.; RESTREPO, I. Wastewater reuse in agriculture: A review about its limitations and benefits. Sustainability (Switzerland), v. 9, n. 10, 2017. https://doi.org/10.3390/su9101734

LAGHARI, A. N.; WALASAI, G. D.; JATOI, A. R.; SHAIKH, F. A.; SIYAL, Z. A. Performance analysis of water filtration units for reduction of $\mathrm{pH}$, Turbidity, Solids and Electricity Conductivity. Engineering, Technology \& Applied Science Research, v. 8, n. 4, p. 3209-3212, 2018.

MERIZALDE, E.; MONTENEGRO, L.; CABRERA, M. Estudio de un Sistema de Tratamiento de Aguas Residuales Provenientes de una Industria de Papel. Revista Politécnica, v. 43, n. 1, p. 07-14, 2019. https://doi.org/10.33333/rp.vol43n1.951 
NOIKONDEE, R.; CHUNKAO, K.; BUALERT, S.; PATTAMAPITOON, T. Evaluation of dissolved oxygen stratification in an oxidation pond for community wastewater treatment through King's Royally initiated "Nature by Nature" process. Environment Asia, v. 12, n. 1, p. 169-177, 2019. https://doi.org/10.14456/ea.2019.19

PEÑA, S.; MAYORGA, J.; MONTOYA, R. Propuesta de tratamiento de las aguas residuales de la ciudad de Yaguachi (Ecuador). Revista Ciencia e Ingeniería, v. 39, n. 2, p. 161 $168,2018$.

PÉREZ-DÍAZ, J. P.; ORTEGA-ESCOBAR, H. M.; RAMÍREZ-AYALA, C.; FLORESMAGDALENO, H.; SÁNCHEZ-BERNAL, E. I.; CAN-CHULIM, Á.; MANCILLAVILLA, O. R. Concentración de nitrato, fosfato, boro y cloruro en el agua del río Lerma. Ecosistemas y Recursos Agropecuarios, v. 6, n. 16, p. 175, 2019. https://doi.org/10.19136/era.a6n16.1829

PERU. Ministerio del Ambiente. Decreto Supremo $\mathrm{n}^{\circ}$ 004-2017-MINAM. Aprueban Estándares de Calidad Ambiental para agua y establecen disposiciones complementarias. El Peruano, Lima, 07 de jun. de 2017.

POIRIER, L.; PINAULT, L.; ARMSTRONG, N.; GHIGO, E.; DAUDÉ, D.; CHABRIÈRE, E. Evaluation of a robust engineered enzyme towards organophosphorus insecticide bioremediation using planarians as biosensors. Chemico-Biological Interactions, v. 306, p. 96-103, 2019. https://doi.org/10.1016/j.cbi.2019.04.013

POMPEI, C. M. E.; CIRIC, L.; CANALES, M.; KARU, K.; VIEIRA, E. M.; CAMPOS, L. C. Influence of PPCPs on the performance of intermittently operated slow sand filters for household water purification. Science of the Total Environment, v. 581-582, p. 174185, 2017. https://doi.org/10.1016/j.scitotenv.2016.12.091

$\mathrm{R}$ DEVELOPMENT CORE TEAM. $\mathbf{R}$ a language and environment for statistical computing. Vienna: R Foundation for Statistical Computing, 2020.

RADZI, E. Z.; WAHAB, M. S.; SAHDAN, M. Z.; HAMDAN, R.; ZAKARIAH, R. A. Gravitational aeration tower filter system to increase the dissolved oxygen amount for iron removal in groundwater. International Journal of Integrated Engineering, v. 12, n. 3, p. 207-215, 2020. https://doi.org/10.30880/ijie.2020.12.03.024

REYES FARJE, J. F.; MORALES ROJAS, E. Eficiencia del tratamiento de aguas residuales utilizando lombrices californianas (Eisenia foétida) y el jacinto acuático (Eichhornia crassipes), Chachapoyas, 2018. Revista de Investigación Científica UNTRM: Ciencias Naturales e Ingeniería, v. 2, n. 1, p. 33-36, 2019. http://dx.doi.org/10.25127/ucni.v2i1.445

RODRÍGUEZ-MIRANDA, J. P.; GÓMEZ, E.; GARAVITO, L.; LÓPEZ, F. Estudio de comparación del tratamiento de aguas residuales domésticas utilizando lentejas y buchón de agua en humedales artificiales. Tecnología y Ciencias del Agua, v. 1, n. 1, p. 59-68, 2010.

RUBIO ARIAS, H. O.; ORTIZ DELGADO, R. C.; QUINTANA MARTÍNEZ, R. M.; SAUCEDO TERÁN, R. A.; OCHOA RIBEIRO, J. M.; REY BURCIAGA, N. I. Índice De Calidad De Agua (ICA) en la presa La Boquilla en Chihuahua, México. Ecosistemas y Recursos Agropecuarios, v. 1, n. 2, p. 139-150, 2014. 
SILVA-TEIRA, A.; VÁZQUEZ-PADÍN, J. R.; WEILER, R.; FERNÁNDEZ-GONZÁLEZ, R.; ROGALLA, F.; GARRIDO, J. M. Performance of a hybrid membrane bioreactor treating a low strength and alkalinity wastewater. Process Biochemistry, v. 66, n. September 2017, p. 176-182, 2018. https://doi.org/10.1016/j.procbio.2017.12.015

STOKHOLM-BJERREGAARD, M.; MCILROY, S. J.; NIERYCHLO, M.; KARST, S. M.; ALBERTSEN, M.; NIELSEN, P. H. A critical assessment of the microorganisms proposed to be important to enhanced biological phosphorus removal in full-scale wastewater treatment systems. Frontiers in Microbiology, v. 8, p. 1-18, 2017. https://doi.org/10.3389/fmicb.2017.00718

TOMASZEWSKI, M.; CEMA, G.; ZIEMBIŃSKA-BUCZYŃSKA, A. Influence of temperature and $\mathrm{pH}$ on the anammox process: A review and meta-analysis. $\begin{array}{lllll}\text { Chemosphere, } & \text { v. } & 182, & \text { p. } & 203-214,\end{array}$ https://doi.org/10.1016/j.chemosphere.2017.05.003 